\title{
Soil organic carbon dynamics under long-term fertilizations in arable land of northern China
}

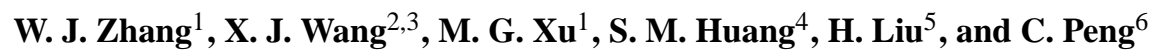 \\ ${ }^{1}$ Ministry of Agriculture Key Laboratory of Crop Nutrition and Fertilization, Institute of Agricultural Resources and Regional \\ Planning, Chinese Academy of Agricultural Sciences, Beijing 100081, China \\ ${ }^{2}$ Xinjiang Institute of Ecology and Geography, Chinese Academy of Sciences, Urumqi, 830000, China \\ ${ }^{3}$ Earth System Science Interdisciplinary Center, University of Maryland, College Park, MD 20740, USA \\ ${ }^{4}$ Inst. of Soil and Fertilizer, Henan Academy of Agricultural Sciences, Zhengzhou, Henan 450002, China \\ ${ }^{5}$ Inst. of Soil and Fertilizer \& Agricultural sparing water, Xinjiang Academy of Agricultural Sciences, Urumqi 830091, China \\ ${ }^{6}$ Inst. of Soil and Fertilizer, Jilin Academy of Agricultural Sciences, ChangChun, 130001, China
}

Received: 22 April 2009 - Published in Biogeosciences Discuss.: 3 July 2009

Revised: 24 December 2009 - Accepted: 7 January 2010 - Published: 2 February 2010

\begin{abstract}
Soil carbon sequestration is a complex process influenced by agricultural practices, climate and soil conditions. This paper reports a study of long-term fertilization impacts on soil organic carbon (SOC) dynamic from six long-term experiments. The experiment sites are located from warm-temperate zone with a double-cropping system of corn (Zea mays L.) - wheat (Triticum Aestivium L.) rotation, to mild-temperate zones with mono-cropping systems of continuous corn, or a three-year rotation of corn-wheatwheat. Mineral fertilizer applications result in an increasing trend in SOC except in the arid and semi-arid areas with the mono-cropping systems. Additional manure application is important to maintain SOC level in the arid and semi-arid areas. Carbon conversion rate is significant lower in the warmtemperate zone with double cropping system (6.8\%-7.7\%) than that in the mild-temperate areas with mono-cropping systems $(15.8 \%-31.0 \%)$. The conversion rate is significantly correlated with annual precipitation and active accumulative temperature, i.e., higher conversion rate under lower precipitation and/or temperature conditions. Moreover, soil high in clay content has higher conversion rate than soils low in clay content. Soil carbon sequestration rate ranges from 0.07 to $1.461 \mathrm{tha}^{-1}$ year $^{-1}$ in the upland of northern China. There is significantly linear correlation between soil carbon sequestration and carbon input at most sites, indicating that these soils are not carbon-saturated thus have potential to migrate more $\mathrm{CO}_{2}$ from atmosphere.
\end{abstract}

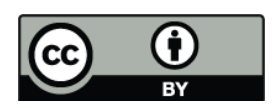

Correspondence to: $\mathrm{M}$. G. Xu (mgxu@caas.ac.cn)

\section{Introduction}

Soil organic carbon (SOC) is an important index of soil fertility because of its relationship to crop productivity (Vinther et al., 2004; Pan et al., 2009). For instance, declining SOC levels often leads to decreased crop productivity (Dominy et al., 2002; Lal, 2006). Thus, maintaining SOC level is essential for agricultural sustainability. The concept of sustainable agricultural production emphasizes the importance of SOC management for food security and environment protection (Buyanovsky and Wagner, 1998; Pan et al., 2009). Because of the potential of agro-ecosystems to absorb a large amount of atmospheric carbon dioxide through soil carbon sequestration, SOC management is recognized as a "win-win strategy" (Smith et al., 1999; Lal, 2002), and has been put forward as one of the mitigating options for global climate change (Post et al., 2004). Particularly, it is estimated that, in China, the potential of soil carbon sequestration may offset more than $10 \%$ of the annual fossil fuel emissions (Lal, 2004).

Soil carbon sequestration is a complex process that is influenced by many factors, such as agricultural practice, and climatic and soil conditions. A number of studies indicate that SOC levels increase under practices of balanced fertilization, organic amendments, cropping rotations, conservative tillage (e.g., no-till), and reduced fallow (Su et al., 2006; Bhattacharyya et al., 2007; Purakayastha et al., 2008; Gong et al., 2009; Tong et al., 2009). Particularly, there is evidence of improved soil fertility and increased carbon sequestration in Chinese croplands due to extensive applications of balanced fertilization over the past 20 years, especially with additional organic materials and/or incorporation of crop residue (Huang and Sun, 2006).

Published by Copernicus Publications on behalf of the European Geosciences Union. 


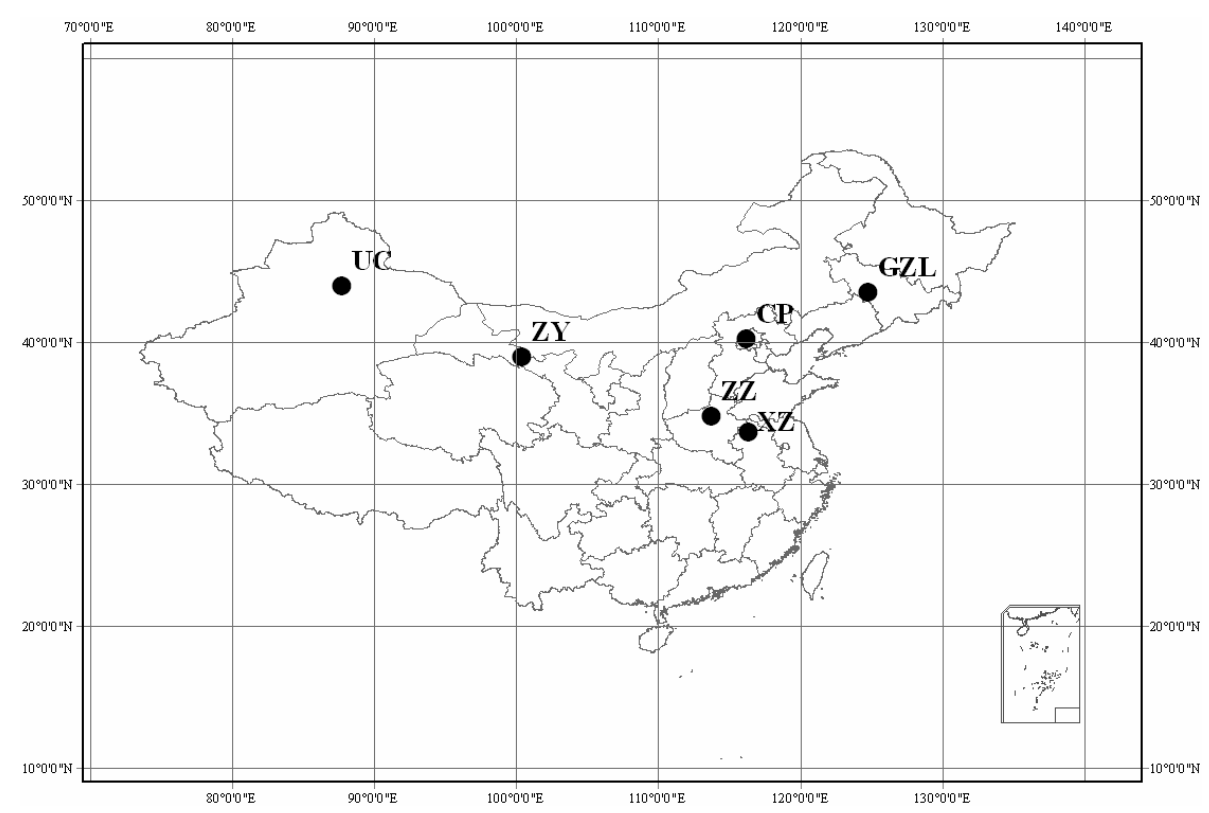

Fig. 1. Locations of the long-term experiment sites. GZL: Gongzhuling; UC: Urumqi, ZY: Zhangye; CP: Changping; XZ: Xuzhou; ZZ: Zhengzhou.

While carbon input may be one of the means to increase SOC content in agro-ecosystems, relationships between SOC level and carbon input are complicated. On the one hand, a few studies demonstrate that SOC level shows a linear increase in response to carbon input (Kundu et al., 2001, 2007; Kong et al., 2005; Campbell et al., 2007). On the other hand, some studies (Six et al., 2002; Gulde et al., 2008; Stewart et al., 2009) show that the SOC content does not increase much even after a large amount of organic material is incorporated into the soil, suggesting that these soils may be saturated with organic carbon.

The complex relationship between SOC and carbon input may be related to climatic conditions and soil properties. Climatic conditions, especially temperature and precipitation, may be responsible for the spatial variations in soil carbon sequestration (Paustian et al., 1998; Freibauer et al., 2004). Favorite temperature and soil moisture can cause high rate of SOC decomposition thus low rate of SOC accumulation (Kätterer et al., 1998; Reichstein et al., 2002). Soil texture or clay content may also affect SOC accumulation and sequestration rate (McLauchlan, 2006). For instance, there is evidence of positive relationship between soil silt plus clay content and SOC sequestration (Gami et al., 2009). In situ and laboratory studies also show that SOC decomposition rate decreases with increasing clay content (Hassink, 1997; Kong et al., 2009).

Currently, China has approximately 137.5 million hectares of arable land with various climatic conditions (NSSO, 1998), from tropical zone in the south to frigid-temperate zone in the north. These arable soils contain approximately $13 \mathrm{Pg}$ SOC (Xie et al., 2007), accounting for $7 \%-12 \%$ of the total SOC pool of arable soils in the world (Schlesinger, 1999). The long history of agricultural cultivation particularly on arable land of China has not only supported Chinese food productivity, but also greatly influenced soil carbon sequestration. For instance, it is estimated that arable land in China has sequestered about $472 \mathrm{Tg}$ SOC during the last 20 years, but meantime there have been $20 \mathrm{Tg}$ SOC lost in the Heilongjiang Province in northeastern China (Xie et al., 2007).

There have been numerous studies addressing SOC dynamics in Chinese agricultural ecosystems located at different climate areas (e.g., Yang et al., 2003; Fan et al., 2005; Cai and Qin, 2006; Su et al., 2006; Gong et al., 2009). However, there is little systematic analysis of climate effects on SOC variations under long-term fertilization. Moreover, litter information is available for multi-site comparisons of SOC dynamics with different cropping systems and under various soil conditions. The objective of this study is to conduct a multi-site analysis to (i) assess the impacts of long-term fertilization practices on SOC dynamics in northern China, and (ii) examine the relationship between soil carbon sequestration and carbon input under various climatic and soils conditions.

\section{Materials and methods}

\subsection{Site descriptions}

This study includes six long-term experiment sites in arable land of the northern China (Fig. 1), with arid mild- 
Table 1. Climatic conditions and cropping system at the long-term experiment sites.

\begin{tabular}{lllllll}
\hline Sites & Climate $^{\mathrm{a}}$ & $\begin{array}{l}\text { Altitude } \\
(\mathrm{m})\end{array}$ & $\begin{array}{l}\mathrm{AMT}^{\mathrm{b}} \\
\left({ }^{\circ} \mathrm{C}\right)\end{array}$ & $\begin{array}{l}\text { Annual P}^{\mathrm{c}} \\
(\mathrm{mm})\end{array}$ & $\begin{array}{l}\text { Annual E } \\
(\mathrm{mm})\end{array}$ & $\begin{array}{l}\text { Cropping } \\
\text { system }^{\mathrm{e}}\end{array}$ \\
\hline Gongzhuling & MT, SH & 220 & 4.5 & 525 & 1400 & MC-CCC \\
Urumqi & MT, SA & 600 & 7.7 & 310 & 2570 & MC-CWW \\
Zhangye & MT, A & 1511 & 7.0 & 127 & 2345 & MC-CWW \\
Changping & WT, SH & 20 & 11 & 600 & 2301 & DC-CW \\
Zhengzhou & WT, SH & 59 & 14.3 & 632 & 1450 & DC-CW \\
Xuzhou & WT, H & 20 & 14.5 & 832 & 2200 & DC-CW \\
\hline
\end{tabular}

${ }^{\text {a }}$ MT, mild-temperate; WT, warm-temperate; A, arid; SA, semi-arid; SH: semi-humid; H, humid

b AMT: annual mean temperature.

c P: precipitation.

d E: evaporation.

e MC: mono-cropping; DC: double-cropping; CCC: corn-corn-corn; CWW: corn-wheat-wheat; CW: corn-wheat.

Table 2. Initial soil physical and chemical properties at the long-term experiment sites.

\begin{tabular}{|c|c|c|c|c|c|c|}
\hline Sites & Gongzhuling & Urumqi & Zhangye & Changping & Zhengzhou & Xuzhou \\
\hline $\begin{array}{l}\text { China soil } \\
\text { classification }\end{array}$ & Black soil & $\begin{array}{l}\text { Grey } \\
\text { desert soil }\end{array}$ & $\begin{array}{l}\text { Irrigated } \\
\text { desert soil }\end{array}$ & $\begin{array}{l}\text { Brown } \\
\text { fluvo-aquic } \\
\text { soil }\end{array}$ & $\begin{array}{l}\text { Fluvo-aquic } \\
\text { soil }\end{array}$ & $\begin{array}{l}\text { Yellow } \\
\text { fluvo-aquic } \\
\text { soil }\end{array}$ \\
\hline FAO soil classification & $\begin{array}{l}\text { Luvic } \\
\text { Phaeozems }\end{array}$ & $\begin{array}{l}\text { Haplic } \\
\text { Calcisol }\end{array}$ & Anthrosol & $\begin{array}{l}\text { Haplic } \\
\text { Luvisol }\end{array}$ & $\begin{array}{l}\text { Calcaric } \\
\text { Cambisol }\end{array}$ & $\begin{array}{l}\text { Calcaric } \\
\text { Cambisol }\end{array}$ \\
\hline $\begin{array}{l}\text { Soil organic carbon } \\
\left(\mathrm{g} \mathrm{kg}^{-1}\right)\end{array}$ & 13.0 & 8.8 & 11.5 & 7.1 & 6.7 & 6.5 \\
\hline Total N $\left(\mathrm{g} \mathrm{kg}^{-1}\right)$ & 1.42 & 0.91 & 0.86 & 0.80 & 0.67 & 0.66 \\
\hline $\mathrm{C} / \mathrm{N}$ ratio & 9.2 & 10.4 & 13.4 & 8.9 & 10.0 & 9.8 \\
\hline Total P $\left(\mathrm{g} \mathrm{kg}^{-1}\right)$ & 1.53 & 0.67 & 0.82 & 1.60 & 0.64 & 0.74 \\
\hline Total $\mathrm{K}\left(\mathrm{g} \mathrm{kg}^{-1}\right)$ & 24.6 & 23.0 & nd & 17.3 & 16.9 & 22.7 \\
\hline Available $\mathrm{N}\left(\mathrm{mg} \mathrm{kg}^{-1}\right)$ & 131.5 & 55.2 & 28.1 & 49.7 & 51.3 & nd \\
\hline Olsen-P (mg kg$\left.{ }^{-1}\right)$ & 23.3 & 3.4 & 21.7 & 12.0 & 6.5 & 12.0 \\
\hline Available $\mathrm{K}\left(\mathrm{mg} \mathrm{kg}^{-1}\right)$ & 160 & 288 & 99 & 88 & 74 & 63 \\
\hline $\mathrm{pH}$ & 7.2 & 8.1 & nd & 8.7 & 8.3 & 8.2 \\
\hline Clay content $(<0.002 \mathrm{~mm})(\%)$ & 32.1 & 20.9 & nd & 10.2 & 13.4 & 6.0 \\
\hline Bulk density $\left(\mathrm{g} \mathrm{cm}^{-3}\right)$ & 1.19 & 1.25 & 1.20 & 1.58 & 1.24 & 1.25 \\
\hline
\end{tabular}

nd: no data.

temperate to humid warm-temperate climate conditions (Table 1). Annual average temperature varied from $4.5^{\circ} \mathrm{C}$ at the Gongzhuling site to $14.5^{\circ} \mathrm{C}$ at the Xuzhou site. Annual precipitation was generally low, ranging from $127 \mathrm{~mm}$ at the Zhangye site in the arid area to $832 \mathrm{~mm}$ at the Xuzhou site in humid area. However, annual evaporation was much higher relative to precipitation, varying from $1400 \mathrm{~mm}$ to $2570 \mathrm{~mm}$. The highest evaporation was found at the Urumqi site, whereas the highest annual precipitation was at the Xuzhou site. In general, $50 \%-70 \%$ of the annual precipitation occurred in the non-growing season. Thus, irrigation was usually applied during the growing season, especially at the two dry sites (i.e., Urumqi and Zhangye). The annual active accumulative temperature, the sum of the daily tempera- ture over $10^{\circ} \mathrm{C}$ during the whole year, ranged from $3100^{\circ} \mathrm{C}$ to $4590^{\circ} \mathrm{C}$ (data from China meteorological sharing service system, http://cdc.cma.gov.cn/).

Soils at the Changping, Zhengzhou, and Xuzhou sites, had the same soil parents (i.e., loess), which had been used for agriculture for a long time before the experiments. For the Urumqi and Zhangye sites (in the arid and semi-arid areas), soils were cultivated with irrigation for a few years before the experiments. Soil classifications by the FAO (FAOUNESCO, 1988) and Chinese system, and basic site descriptions are presented in Table 2.

The initial SOC content was considerably higher at the Gongzhuling, Urumqi, and Zhangye sites with the monocropping systems than the other three sites with the double- 
Table 3. Experiment design for the long-term experiments.

\begin{tabular}{lllllll}
\hline Sites/treatment & Gongzhuling & Urumqi & Zhangye & Changping & Zhengzhou & Xuzhou \\
\hline Plot size $\left(\mathrm{m}^{2}\right)$ & 400 & 468 & 33.3 & 200 & 400 & 33.3 \\
Replicates & 1 & 1 & 3 & 1 & 1 & 4 \\
Control & + & + & + & + & + & + \\
N & + & + & + & + & + & + \\
NP & + & + & + & + & + & + \\
NPK & + & + & + & + & + & + \\
NPM & - & - & + & - & - & + \\
NPKM & + & + & + & + & + & + \\
hNPKM & + & + & - & + & + & - \\
NPKS & + & + & - & + & + & - \\
\hline
\end{tabular}

$+:$ the treatment is included; $-:$ the treatment is not included.

cropping systems. The initial total and available soil nutrients and clay content at the Gongzhuling site were the highest, suggesting that soil fertility at this site was relatively higher than other sites. While the $\mathrm{C} / \mathrm{N}$ ratio was around 10 for most sites, the Zhangye site had a value of 13.4, suggesting that soil organic matter might be difficult to decompose at this site. Soil $\mathrm{pH}$ had a range of 7.2-8.7.

\subsection{Cropping practices}

The long-term experiment had a mono-cropping system at the Gongzhuling, Urumqi, and Zhangye sites, and a doublecropping system at the Changping, Zhengzhou, and Xuzhou sites (Table 1). The main crops were corn (Zea mays L.) and wheat (Triticum Aestivium L.). The double cropping system had a rotation of summer corn (seeded in late April to early May) and winter wheat (seeded in October). The mono-cropping systems had a continuous corn cropping at the Gongzhuling site, but a rotation of corn-wheat-wheat (i.e., corn cropping for one year and wheat cropping for next two years) at the Zhangye and Urumqi sites. Corn was seeded during late April to early May for the mono-cropping system. Wheat was seeded in March (spring wheat) at the Zhangye site. For the Urumqi site, spring wheat was seeded in mid-April and winter wheat in late September in the same year. Prior to the experiment, the field had been under the same rotation for 2-3 years at each site.

The seeding rate for wheat (spring and winter wheat) ranged from $300-390 \mathrm{~kg} \mathrm{ha}^{-1}$ for the Urumqi and Zhangy sites, $165-225 \mathrm{~kg} \mathrm{ha}^{-1}$ for the Changping, Zhengzhou and Xuzhou sites. The seeding space for corn was approximately $65 \mathrm{~cm}$ by $30 \mathrm{~cm}$ at all sites. The number of corn seedling was about $63000-75000$ per hectare. Seeds were planted by seeding-machine to $3-5 \mathrm{~cm}$ below the soil surface.

Wheat straw and corn stover were cut to ground after the grain harvest. Thus, only roots and litters were left in the soil. All above-ground materials were removed from the fields. Crop grain and residue were air-dried, threshed, oven- dried at $70{ }^{\circ} \mathrm{C}$ to a uniform moisture level, and then weighted separately.

\subsection{Fertilization treatments}

There were five common treatments at all sites: nonfertilization (control), mineral nitrogen $(\mathrm{N})$, mineral nitrogen and phosphorus combination (NP), mineral nitrogen, phosphorus and potassium combination (NPK), and NPK combinations with livestock or farmyard manure (NPKM) (Table 3). For the Gongzhuling, Urumqi, Changping, and Zhengzhou sites, there were two additional fertilization treatments: higher application rate of NPKM (hNPKM), and mineral NPK combined with crop residue (NPKS). There was an additional treatment at the Zhangye and Xuzhou sites: mineral NP combined with manure (NPM). The Gongzhuling, Urumqi, Zhengzhou, and Changping sites had large experiment plots $\left(200-468 \mathrm{~m}^{2}\right)$ without replicate, whereas the Zhangye and Xuzhou sites had small plots $\left(33.3 \mathrm{~m}^{2}\right)$ with 3 and 4 replicates. These plots were isolated by $100-\mathrm{cm}-$ cement baffle plates.

The mineral nitrogen, phosphorus and potassium fertilizers were urea, calcium superphosphate, and potassium chloride, respectively. At the Gongzhuling, Urumqi, and Changping sites, the total nitrogen applied (i.e., mineral plus organic) was equal (i.e., nitrogen balanced) for the N, NP, NPK, and NPKM treatments (Table 4). The Zhangye and Xuzhou sites had the same application rates of mineral nitrogen for all the treatments thus the total nitrogen applied in the NPKM treatment was higher than the other treatments (thus these sites were nitrogen unbalanced). For the NPKM treatment at the nitrogen balanced sites, $30 \%$ of total nitrogen was mineral, and the rest organic (Table 5). The application rates of mineral and organic fertilizers for the hNPKM treatment were 1.5 times of those for the NPKM treatments at the Gongzhuling, Changping, and Zhengzhou sites. For the Urumqi site, the rates of mineral (organic) fertilizers were two-third (2 times) of those for the NPKM. The source of 
Table 4. Application rates $\left(\mathrm{kg} \mathrm{ha}^{-1}\right)$ of mineral nitrogen for each growing season under various fertilization treatments.

\begin{tabular}{|c|c|c|c|c|c|c|}
\hline Sites & Periods & Crops & N/NP/NPK & NPM/NPKM & hNPKM & NPKS \\
\hline Gongzhuling & 1990-2005 & Corn & 165 & 50 & 74 & 165 \\
\hline \multirow[t]{4}{*}{ Urumqi } & 1990-1994 & Corn/wheat & 99 & 30 & 60 & 89 \\
\hline & 1995-1998 & Corn/wheat & 242 & 85 & 152 & 217 \\
\hline & 1999 & Cotton & 242 & 85 & 152 & 217 \\
\hline & 2000-2005 & Corn/wheat & 242 & 85 & 152 & 217 \\
\hline \multirow[t]{6}{*}{ Zhangye } & 1982-1990 & Corn & 240 & 240 & - & - \\
\hline & & Wheat & 120 & 120 & - & - \\
\hline & 1991-2002 & Corn & 300 & 300 & - & - \\
\hline & & Wheat & 150 & 150 & - & - \\
\hline & 2000 & Corn & 450 & 450 & - & - \\
\hline & 2003 & Corn & 360 & 360 & - & - \\
\hline \multirow[t]{2}{*}{ Changping } & 1990-2005 & Corn & 150 & 50 & 225 & 150 \\
\hline & & Wheat & 150 & 50 & 225 & 150 \\
\hline \multirow[t]{2}{*}{ Zhengzhou } & 1990-2005 & Corn & 188 & 188 & 282 & 188 \\
\hline & & Wheat & 165 & 49.5 & 74.2 & 49.5 \\
\hline \multirow[t]{2}{*}{ Xuzhou } & 1981-2001 & Corn & 150 & 150 & - & - \\
\hline & & Wheat & 150 & 150 & - & - \\
\hline
\end{tabular}

Table 5. Manure properties and annual carbon input due to application of manure/straw for relevant fertilization treatments.

\begin{tabular}{|c|c|c|c|c|c|c|c|c|c|}
\hline \multirow[t]{2}{*}{ Sites } & \multirow[t]{2}{*}{ Period } & \multirow[t]{2}{*}{ Crops } & \multicolumn{3}{|c|}{ Manure properties } & \multicolumn{4}{|c|}{ Carbon input ( $\left.\mathrm{tha}^{-1}\right)$} \\
\hline & & & Source $\dagger$ & Carbon $\left(\mathrm{g} \mathrm{kg}^{-1}\right)$ & $\mathrm{C} / \mathrm{N}$ ratio & NPM & NPKM & hNPKM & NPKS \\
\hline Gongzhuling & $1990-2005$ & Corn & HM & 36.0 & 20 & - & 3.86 & 5.79 & 0.93 \\
\hline Urumqi & 1990-2005 & Corn/wheat/cotton & GM & 33.6 & 17 & - & 2.82 & 5.64 & 1.47 \\
\hline \multirow[t]{2}{*}{ Zhangye } & $\begin{array}{l}1982-1990 \\
2002-2003\end{array}$ & Corn/wheat & FYM-soil & 13.5 & 11 & 0.55 & 0.55 & - & - \\
\hline & 1991-2001 & Corn/wheat & FYM- soil & 13.5 & 11 & 0.68 & 0.68 & - & - \\
\hline \multirow[t]{2}{*}{ Changping } & 1990-2005 & Corn & - & - & - & - & 0 & 0 & 0 \\
\hline & & Wheat & FYM-S & 17.4 & 20 & - & 3.15 & 4.72 & 1.00 \\
\hline \multirow[t]{2}{*}{ Zhengzhou } & 1990-2005 & Corn & - & - & - & - & 0 & 0 & 0 \\
\hline & & wheat & $\mathrm{HM}$ & 36.0 & 20 & - & 4.89 & 7.33 & 1.32 \\
\hline \multirow[t]{4}{*}{ Xuzhou } & 1981-1984 & Corn & HM & 36.0 & 20 & 4.80 & 4.80 & - & - \\
\hline & & Wheat & $\mathrm{HM}$ & 36.0 & 20 & 4.80 & 4.80 & - & - \\
\hline & 1985-2001 & Corn & $\mathrm{CM}$ & 36.8 & 23 & 2.40 & 2.40 & - & - \\
\hline & & Wheat & $\mathrm{CM}$ & 36.8 & 23 & 2.40 & 2.40 & - & - \\
\hline
\end{tabular}

$\dagger$ HM: horse manure; GM: goat manure; CM: cow manure; FYM-soil: farmyard manure mixed with soil;

FYM-S: farmyard manure mixed with crop residue.

organic manure includes farmyard manure and pure manure from household livestock such as horse, goat, and cattle (Table 5). At the Zhangye and Changping sites, farmyard manure was mixed with soil and/or crop residue. Manure was applied before seeding once a year for all sites. For the double cropping system, manure was applied before wheat seeding. For the NPKS treatment, crop straw was incorporated in situ annually. The entire yield of corn or wheat straw was incorporated at the Urumqi and Gongzhuling sites. All of the amount of corn straw yield under the NPKS treatment was incorporated at the Zhengzhou site, while corn straw was incorporated at a rate of $2.25 \mathrm{tha}^{-1}$ for the Changping site.
The annual application rate of nitrogen was 195$242 \mathrm{~kg} \mathrm{ha}^{-1}$ for the mono-cropping systems and 300$353 \mathrm{~kg} \mathrm{ha}^{-1}$ for the double-cropping system (Table 4). Onethird of nitrogen fertilizer was applied as base fertilizer before seeding and the rest as topdressing at the jointing stage at the Gongzhuling site. For the Urumqi, Changping and Zhengzhou sites, $60 \%$ of nitrogen fertilizer was applied as base fertilizer before seeding and $40 \%$ as topdressing at the jointing stage. At the Xuzhou sites, $50 \%$ of nitrogen fertilizer was applied as base fertilizer and the other $50 \%$ as topdressing for wheat and corn. This application rate was also used for wheat at the Zhangye site. However, for corn, 
approximately $30 \%$ of the nitrogen fertilizer was applied before seeding, $30 \%$ for the jointing/elongation, and $40 \%$ for the 10- to 12-leaf (pretasseling) stages of corn at the Zhangye site, respectively. The application rate of phosphorus fertilizer was $30 \%$ of that for nitrogen fertilizer at the Urumqi site, and $20 \%$ of that at the other sites. The application rate of potassium fertilizer was $20 \%$ of that for nitrogen fertilizer at the Changping and Urumqi sites, $40 \%$ for the Gongzhuling, Zhengzhou and Zhangye sites, and $60 \%$ of that at the Xuzhou site. All the phosphorus and potassium fertilizers were applied as base fertilizers before seeding at each site.

\subsection{Soil sample analyses}

Soil samples were collected from the topsoil $(0-20 \mathrm{~cm})$ each year after harvest (i.e., during September-October). There were 5-10 (20-40) cores in 5-cm-diam, randomly sampled for each plot with (without) replicates. The soil samples of these cores were mixed thoroughly, and air dried for seven days. Air-dried soil was sieved through $2 \mathrm{~mm}$ screen to determine $\mathrm{pH}(1: 1 \mathrm{w} / \mathrm{v}$ water) and other soil properties. Representative sub-samples were crashed to $0.25 \mathrm{~mm}$ for measurements of SOC, total nitrogen (TN), total phosphorus (TP), and total potassium (TK).

Soil organic carbon content was determined by vitriol acid-potassium dichromate oxidation (Walkley and Black, 1934). Total nitrogen was determined by the method described by Black (1965), TP by Murphy and Riley (1962), and TK by Kundsen et al. (1982). Available nitrogen was measured following the method of Lu (2000). Available phosphorus (Olsen-P) was determined by the Olsen-P method (Olsen et al., 1954), and available potassium by Soil Science Society of China (Soil Science Society of China, 2000). Three replicates were carried out for each analysis.

\subsection{Estimations of carbon input, soil carbon sequestra- tion and conversion rate}

Carbon input into topsoil included organic materials from the root system, and addition of organic manure or crop residue return. The annual rates of carbon input by roots in corn and wheat were estimated as $30 \%$ of the above-ground carbon biomass (Chander et al., 1997; Kuzyahov and Domenski, 2000; Kundu et al., 2007).

For the Zhangye and Xuzhou sites where only grain yield data were available, above-ground biomass were estimated using a grain to straw ratio of 1:1.1 for wheat and 1:1.2 for corn (NCATS, 1994). For all the treatments, organic carbon contents were taken as national averaged values, i.e., $39.9 \mathrm{~g} \mathrm{~kg}^{-1}$ and $44.4 \mathrm{~g} \mathrm{~kg}^{-1}$ (at oven-dried base) for wheat and corn, respectively (NCATS, 1994). For the NPKS treatment, organic carbon contents in corn and wheat straw incorporated in situ were taken as 12.4 and $27.8 \mathrm{~g} \mathrm{~kg}^{-1}$ (at fresh base), respectively.
Trend in SOC content $\left(a, \mathrm{~g} \mathrm{~kg}^{-1} \mathrm{yr}^{-1}\right)$ was determined by a linear change over the duration of experiment. Soil carbon sequestration rate $\left(\mathrm{C}_{\text {rate }}, \mathrm{tha}^{-1} \mathrm{yr}^{-1}\right)$ was estimated for the top $20 \mathrm{~cm}$ :

$\mathrm{C}_{\text {rate }}=\frac{a \times \mathrm{BD} \times d}{10}$

where $\mathrm{BD}\left(\mathrm{g} \mathrm{cm}^{-3}\right)$ is the initial value of the soil bulk density, and $d$ the soil depth $(20 \mathrm{~cm})$. The conversion rate of carbon input to SOC was the slope of linear regresiion between annual SOC sequestered and carbon input (Kong et al., 2005; Kundu et al., 2007)

\subsection{Statistical analyses}

The ANOVA and least-signifcant-differenc (LSD) methods were applied to compare above-ground carbon biomass and SOC contents among various fertilization treatments for the third five-year period (i.e., from the 11th to 15 th year of fertilization) in SPSS 11.5.

\section{Results}

\subsection{Above-ground carbon biomass and carbon input}

Figure 2 shows annual changes in the above-ground carbon biomass under various fertilizations. Clearly, the control has the lowest carbon biomass $\left(\sim 4 \mathrm{tCha}^{-1}\right)$ with a decreasing trend at all sites. Most fertilization treatments show a pronounced increase $(>50 \%)$ in carbon biomass during the $15-$ 23 years of experiment. The exception is that the $\mathrm{N}$ treatment has variable effects on the carbon biomass, showing little changes at the Changping and Zhengzhou sites, small increases at the Urumqi and Zhangye sites and moderate increases at the Gongzhuling and Xuzhou sites. Overall, the NPKM and/or hNPKM treatments lead to the highest carbon biomass. There are large inter-annual fluctuations with extremely low carbon biomass $\left(\sim 4 \mathrm{tC} \mathrm{ha}^{-1}\right)$ for some years at the Zhangye site with a desert soil, where crop production is more sensitively to precipitation. Interestingly, the Xuzhou site has the highest carbon biomass $\left(\sim 12 \mathrm{tC} \mathrm{ha}^{-1}\right)$ during the initial few years of fertilization despite of the lowest initial SOC and total N contents. Mineral fertilizer and manure combinations result in more than $100 \%$ increase in carbon biomass at the Xuzhou site. However, there is a clear decreasing trend under the control and mineral applications during the last ten years.

There is evidence that $\mathrm{N}$ application can increase grain yields and biomass (He et al., 2006). In this study, the $\mathrm{N}$ application shows a significant effect on carbon biomass during the third five-year period (i.e., from the 11th to 15 th years of fertilization in Fig. 2) at the Gongzhuling and Xuzhou sites (Table 6). All other fertilization treatments significantly increase carbon biomass except on the grey desert soil (e.g., the Urumqi site under the highest annual evaporation) where 

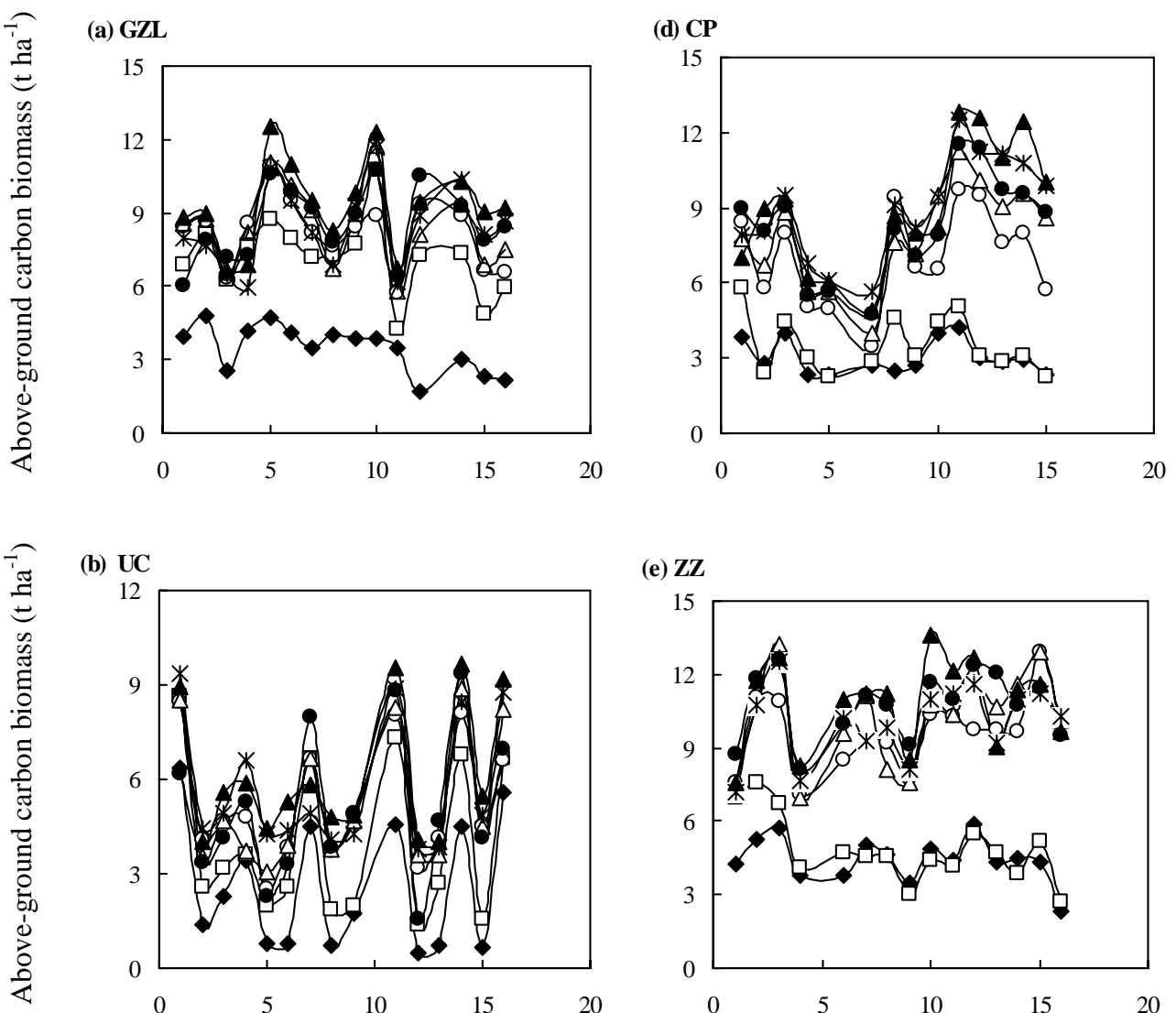

(e) ZZ
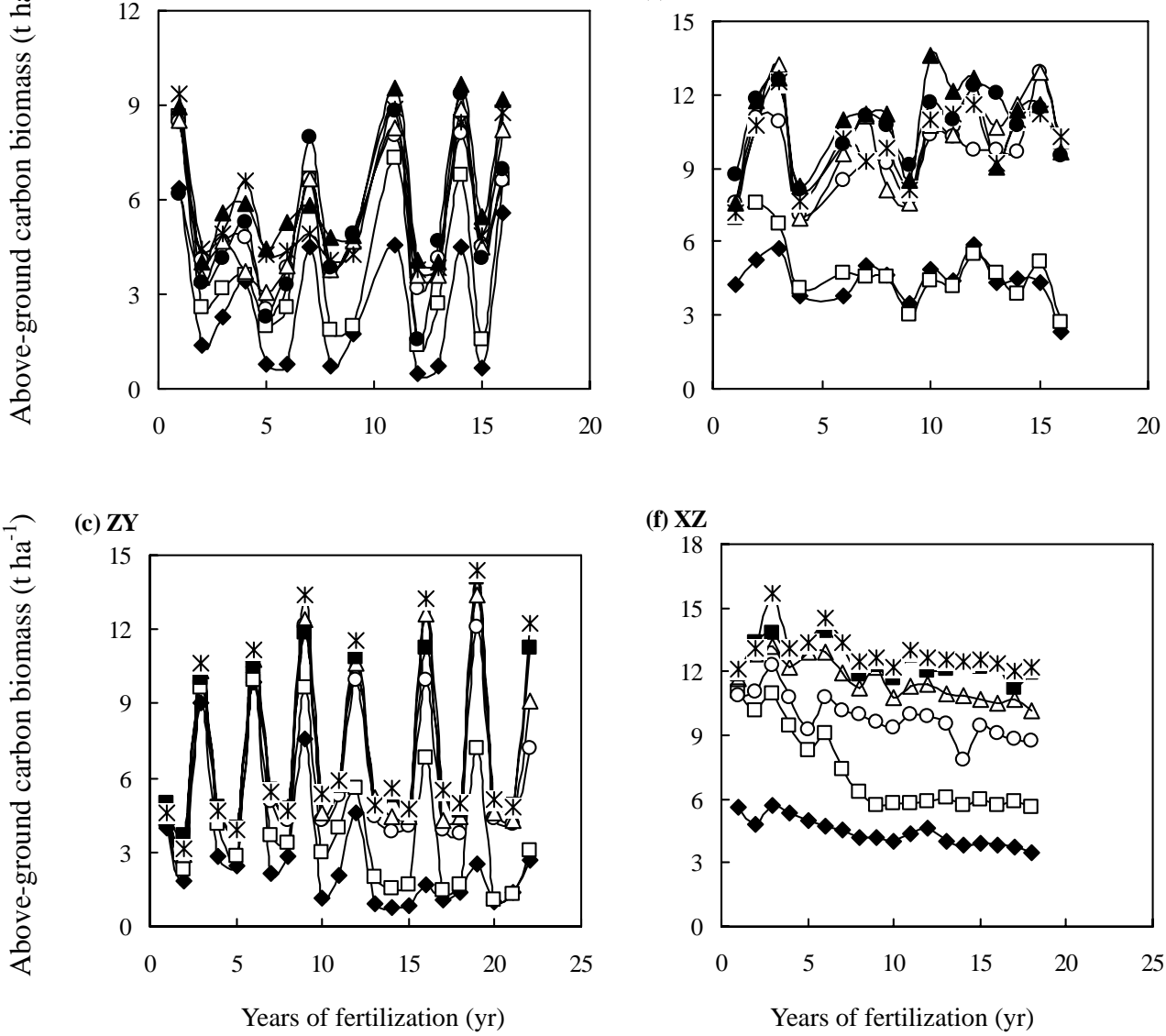

Fig. 2. Annual total above-ground carbon biomass under various long-term fertilizations.

Control, $\square \mathrm{N}, \bigcirc \mathrm{NP}, \triangle \mathrm{NPK}$,

NPM, * NPKM, $\Delta$ hNPKM, NPKS.

only the hNPKM treatment results in a significant increase of biomass. In general, carbon biomass in the double-cropping system is approximately two times of those in the monocropping systems except for the Gongzhuling site where soil has the highest values of initial SOC, total and available N, $\mathrm{P}$ and $\mathrm{K}$. There are no significant differences in the carbon biomass among the NPK, NPKM, hNPKM, and NPKS treat- ments except for the Xuzhou site, indicating that manure application has no significant effect on the above-ground carbon biomass at most sites.

The averaged annual total carbon input shows a significant increase under the $\mathrm{N}$ treatment except for the Changping site (Fig. 3). The amount of carbon input under the control and $\mathrm{N}$ application ranges from 0.81 to $2.18 \mathrm{tha}^{-1}$ at all sites. The 


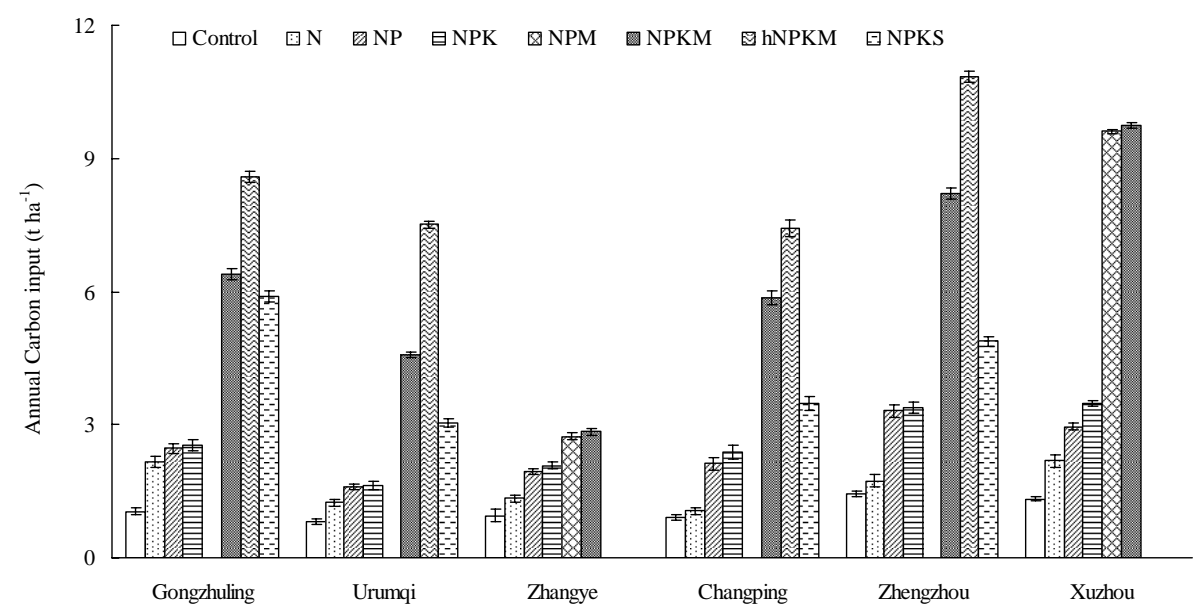

Fig. 3. Annual carbon input ( \pm S.E.) averaged over the entire experiment periods under various fertilizations.

Table 6. Above-ground carbon biomass $\left(\mathrm{tha}^{-1}\right)$ averaged for the third five-year period (i.e., from the 11 th to 15 th years) of fertilization.

\begin{tabular}{lllllll}
\hline Treatments & Gongzhuling & Urumqi & Zhangye & Changping & Zhengzhou & Xuzhou \\
\hline Control & $2.86 \mathrm{a}$ & $2.17 \mathrm{a}$ & $1.73 \mathrm{a}$ & $3.24 \mathrm{a}$ & $4.73 \mathrm{a}$ & $4.12 \mathrm{a}$ \\
N & $6.88 \mathrm{~b}$ & $3.96 \mathrm{ab}$ & $2.96 \mathrm{ab}$ & $3.48 \mathrm{a}$ & $4.62 \mathrm{a}$ & $5.89 \mathrm{~b}$ \\
NP & $7.90 \mathrm{~b}$ & $5.58 \mathrm{ab}$ & $5.32 \mathrm{bc}$ & $7.84 \mathrm{~b}$ & $10.45 \mathrm{~b}$ & $9.34 \mathrm{c}$ \\
NPK & $8.40 \mathrm{~b}$ & $5.77 \mathrm{ab}$ & $5.85 \mathrm{c}$ & $9.68 \mathrm{c}$ & $11.32 \mathrm{bc}$ & $11.02 \mathrm{~d}$ \\
NPM & - & - & $6.10 \mathrm{c}$ & - & - & $12.17 \mathrm{e}$ \\
NPKM & $9.04 \mathrm{~b}$ & $5.96 \mathrm{ab}$ & $6.35 \mathrm{c}$ & $10.83 \mathrm{c}$ & $10.86 \mathrm{bc}$ & $12.59 \mathrm{e}$ \\
hNPKM & $9.58 \mathrm{~b}$ & $6.56 \mathrm{~b}$ & - & $11.18 \mathrm{c}$ & $11.74 \mathrm{c}$ & - \\
NPKS & $9.24 \mathrm{~b}$ & $5.72 \mathrm{ab}$ & - & $9.81 \mathrm{c}$ & $11.56 \mathrm{bc}$ & - \\
\hline
\end{tabular}

Values followed by the same letter in one column indicate that there is no significant difference $(p=0.05)$.

annual rates of carbon input for the NP and NPK treatments are significantly higher than that of the $\mathrm{N}$ treatment. There is no significant difference in annual carbon input between the NP and NPK treatments except for the Xuzhou site. Obviously, with the additional carbon from manure and/or crop residue, the annual carbon inputs in the NPKM and NPKS treatments are much higher than that of the mineral applications (Fig. 3). Among the mono-cropping systems, the annual rate of carbon input under the NPKM treatment are 6.4 and $4.6 \mathrm{tha}^{-1}$ at the Gongzhuling and Urumqi sites, respectively, which are approximately 2-3 times of that at the Zhangye site. For the double cropping systems, the annual rate of carbon input for the NPKM treatment ranges from 5.9 to $9.7 \mathrm{tha}^{-1}$.

\subsection{Soil organic carbon and carbon sequestration rate}

Soil organic carbon level remains low for the control and the mineral fertilization treatments (i.e. N, NP, and NPK) with a decreasing trend except for the Changping site that has the lowest initial $\mathrm{C} / \mathrm{N}$ ratio (8.9) (Fig. 4). As expected, SOC content is relatively high under manure applications (e.g. the
NPM, NPKM, hNPKM treatments), showing an increasing trend. Particularly, the Xuzhou site, with the highest carbon biomass $\left(\sim 12 \mathrm{tha}^{-1}\right)$, shows a pronounced increase under the manure applications over the first ten years, and maintains at a high stable level over the last ten years of fertilization. At the end of the studied periods, SOC is nearly two times of the initial value under the NPKM and hNPKM treatments except for the Zhangye and Changping sites where farmyard manure are applied.

Soil organic carbon content decreases significantly under the control and $\mathrm{N}$ application at the Zhangye site but increase significantly at the Changping site (Table 7). The former has the highest initial soil $\mathrm{C} / \mathrm{N}$ ratio, while the latter has the lowest initial soil $\mathrm{C} / \mathrm{N}$ ratio. Among the monocropping systems, the NPK application has various effects on SOC. The Gongzhuling site, with the highest carbon biomass (Table 6), maintains the initial SOC level, whereas the Urumqi site shows a significant decrease in SOC. For all the double-cropping systems, SOC shows a significantly increasing trend under the NPK application. The manure applications increase SOC significantly at all sites. The SOC increasing rate for the NPKM treatment is much higher at 


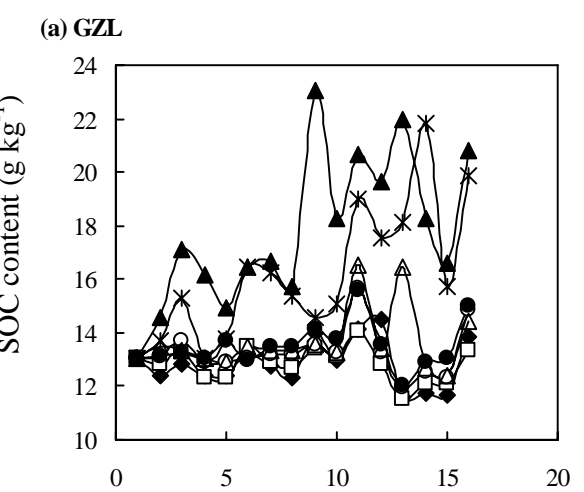

(b) UC

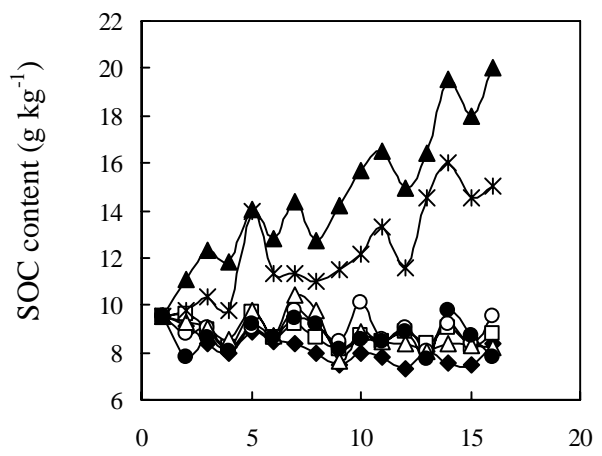

(c) ZY

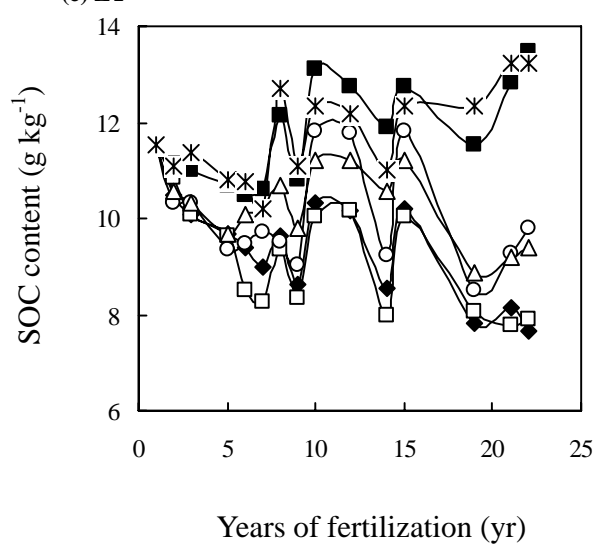

(d) $\mathrm{CP}$

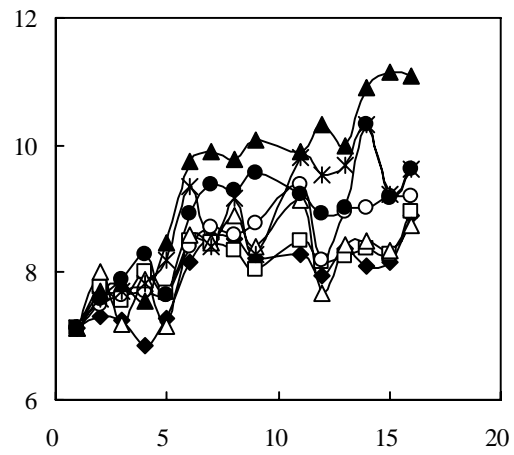

(e) ZZ

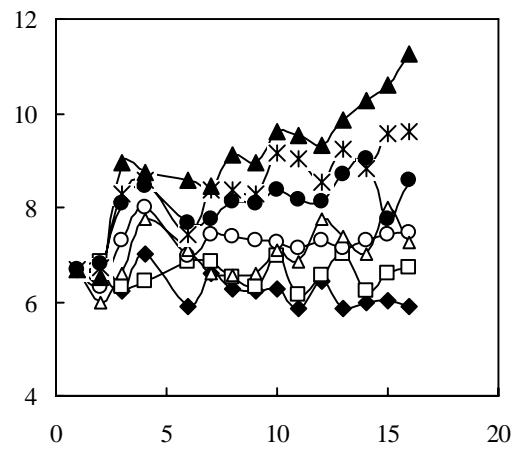

(f) $\mathrm{XZ}$

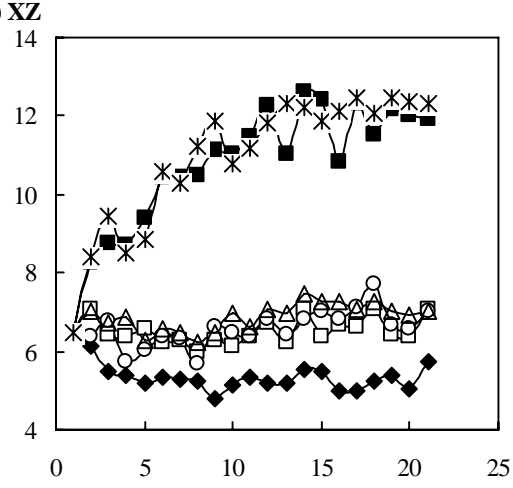

Years of fertilization (yr)

Fig. 4. Soil organic carbon content in topsoil $(0-20 \mathrm{~cm})$ under long-term fertilizations.

Control, $\square \mathrm{N}, \bigcirc \mathrm{NP}, \triangle \mathrm{NPK}, \square \mathrm{NPM}, * \mathrm{NPKM}$, $\Delta$ hNPKM, ${ }_{\text {NPKS. }}$

the Gongzhuling and Urumqi sites $\left(0.36-0.41 \mathrm{~g} \mathrm{~kg}^{-1} \mathrm{yr}^{-1}\right)$ than that at the Zhangye site $\left(0.1 \mathrm{~g} \mathrm{~kg}^{-1} \mathrm{yr}^{-1}\right)$ where the annual carbon input is the lowest. The annual change rate of SOC under manure application varies from 0.16 to $0.24 \mathrm{~g} \mathrm{~kg}^{-1} \mathrm{yr}^{-1}$ in the double cropping systems. For the NPKS treatment, SOC content shows little change in the mono-cropping systems, but a significantly increasing trend in the double-cropping systems.
Figure 5 reveals averaged value of soil carbon sequestration rate over the entire experiment periods. Under the control and $\mathrm{N}$ treatment, most sites show a loss for SOC. The largest losses are found at the two dry sites (Urmqi and Zhangye) with the mono-cropping system, showing a rate of 0.23 and $0.30 \mathrm{tha}^{-1} \mathrm{yr}^{-1}$ under control, respectively. Balanced mineral fertilizer application (i.e., NPK) result in $0.08-0.25 \mathrm{tha}^{-1} \mathrm{yr}^{-1}$ carbon sequestered in soils with the double-cropping system, but a lose rate of 0.22 and 


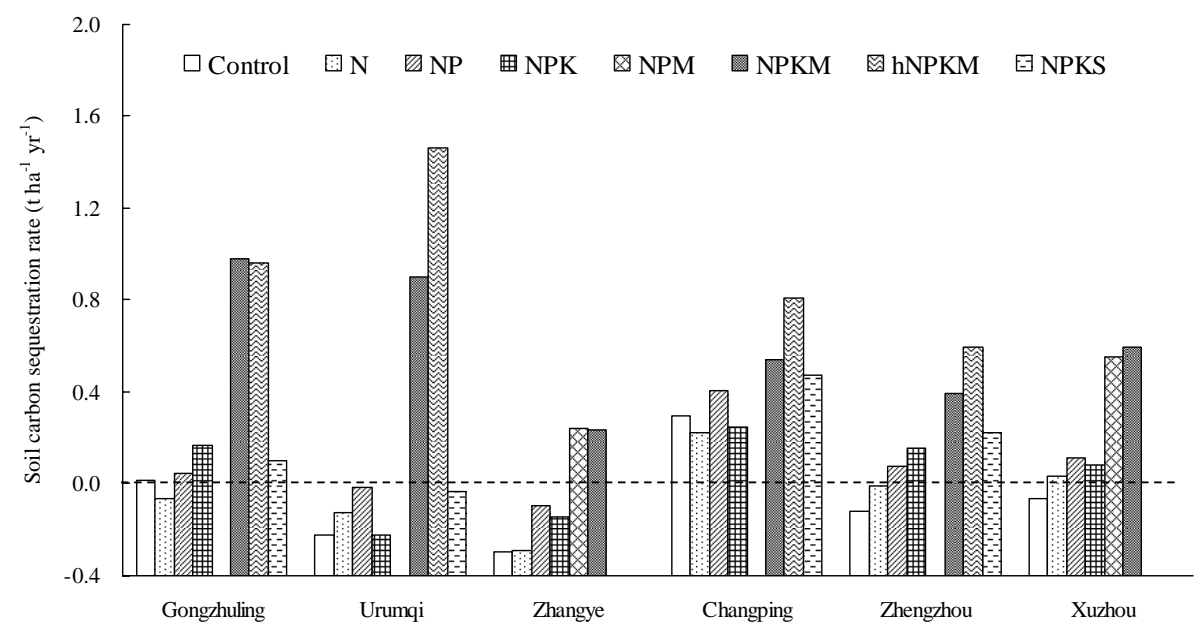

Fig. 5. Soil carbon sequestration rate averaged over the entire period of fertilizations.

Table 7. Change rate of topsoil $(0-20 \mathrm{~cm})$ SOC content $\left(\mathrm{g} \mathrm{kg}^{-1} \mathrm{yr}^{-1}\right)$ (i.e., slope values of linear relationship of SOC content and fertilization duration from Fig. 4).

\begin{tabular}{lllllll}
\hline Treatments & Gongzhuling & Urumqi & Zhangye & Changping & Zhengzhou & Xuzhou \\
\hline CK & 0.006 & $-0.090^{* *}$ & $-0.125^{* *}$ & $0.094^{* *}$ & $-0.049^{* *}$ & -0.026 \\
N & -0.026 & -0.050 & $-0.121^{* *}$ & $0.070^{* *}$ & -0.003 & 0.014 \\
NP & 0.019 & -0.006 & -0.039 & $0.129^{* * *}$ & 0.03 & $0.045^{* *}$ \\
NPK & 0.070 & $-0.089^{*}$ & $-0.060^{*}$ & $0.078^{*}$ & $0.063^{*}$ & $0.033^{* *}$ \\
NPM & - & - & $0.10^{* *}$ & - & - & $0.22^{* * *}$ \\
NPKM & $0.41^{* * *}$ & $0.36^{* * *}$ & $0.10^{* *}$ & $0.17^{* * *}$ & $0.16^{* * *}$ & $0.24^{* * *}$ \\
hNPKM & $0.403^{* *}$ & $0.59^{* * *}$ & - & $0.26^{* * *}$ & $0.24^{* * *}$ & - \\
NPKS & 0.043 & -0.014 & - & $0.15^{* * *}$ & $0.09^{* *}$ & - \\
\hline
\end{tabular}

Significance is marked with one $(p<0.05)$, two $(p<0.01)$, or three $(p<0.001)$ asterisks.

$0.14 \mathrm{tha}^{-1} \mathrm{yr}^{-1}$ at the Urumqi and Zhangye sites, respectively. Manure applications (e.g. NPM, NPKM, hNPKM) result in significant carbon sequestration at all sites, varying from 0.10 to $1.46 \mathrm{tha}^{-1} \mathrm{yr}^{-1}$ in the mono-cropping system, and 0.22 to $0.81 \mathrm{tha}^{-1} \mathrm{yr}^{-1}$ in the double-cropping system.

Further analyses indicate that, mineral fertilizer applications show no effect on SOC at the Gongzhuling and Urumqi sites with the mono-cropping systems (Table 8). The $\mathrm{N}$ and NPK treatments show no effect on SOC at the Zhangye and Changping site, which has the highest and lowest $\mathrm{C} / \mathrm{N}$ ratio, respectively. Mineral fertilizer applications increase SOC significantly by $8.2 \%-34 \%$ at the Zhengzhou and Xuzhou sites. As expected, manure applications show significant effects on SOC at all sites. Among the mono-cropping systems, the NPKM treatment results in an increase of SOC content by $40 \%$ and $78 \%$ at the Gongzhuling and Urumqi, respectively, which are about 2 and 3.5 times of that at the Zhangye site. For the double-cropping systems, manure applications increase SOC content by $18 \%-123 \%$. The NPKS treatment has no effect at sites with mono-cropping system, but significant effects on SOC at sites with double cropping systems.

There are significantly positive, linear correlations between annual SOC sequestered and carbon input at all sites (Fig. 6). The conversion rates at sites in the mild-temperate areas with mono-cropping systems are 2-4 times of those at the warm-temperate areas with double cropping system. The highest conversion rate $(31.0 \%)$ is found at the Zhangye site with arid climate, followed by $26.7 \%$ at the Urumqi site and $15.8 \%$ at the Gongzhuling site. For the double-cropping systems, the conversion rate has a range of $6.8 \%-7.7 \%$.

Figure 7 shows that there are significantly negative correlations between the conversion rate and annual precipitation and active accumulative temperature. Although there is no significant relationship between the conversion rate and soil clay content, the conversion rate is much higher at the sites (26.7\% and $15.8 \%)$ with high soil clay content than that at the sites $(6.8 \%-7.7 \%)$ with low soil clay content. 
Table 8. Topsoil $(0-20 \mathrm{~cm})$ SOC content $\left(\mathrm{g} \mathrm{kg}^{-1}\right)$ averaged for the third five-year period of fertilizations.

\begin{tabular}{lllllll}
\hline Sites & Gongzhuling & Urumqi & Zhangye & Changping & Zhengzhou & Xuzhou \\
\hline Control & $12.8 \mathrm{a}$ & $7.7 \mathrm{a}$ & $9.8 \mathrm{ab}$ & $8.2 \mathrm{a}$ & $6.1 \mathrm{a}$ & $5.3 \mathrm{a}$ \\
N & $12.6 \mathrm{a}$ & $8.6 \mathrm{a}$ & $9.5 \mathrm{a}$ & $8.3 \mathrm{a}$ & $6.6 \mathrm{~b}$ & $6.5 \mathrm{~b}$ \\
NP & $13.2 \mathrm{a}$ & $8.9 \mathrm{a}$ & $11.2 \mathrm{c}$ & $9.0 \mathrm{bc}$ & $7.3 \mathrm{c}$ & $6.7 \mathrm{bc}$ \\
NPK & $14.1 \mathrm{a}$ & $8.4 \mathrm{a}$ & $11.0 \mathrm{bc}$ & $8.4 \mathrm{ab}$ & $7.4 \mathrm{c}$ & $7.1 \mathrm{c}$ \\
NPM & - & - & $12.6 \mathrm{~d}$ & - & - & $11.8 \mathrm{~d}$ \\
NPKM & $17.9 \mathrm{~b}$ & $13.7 \mathrm{~b}$ & $12.0 \mathrm{~cd}$ & $9.7 \mathrm{~d}$ & $9.1 \mathrm{e}$ & $11.7 \mathrm{~d}$ \\
hNPKM & $19.2 \mathrm{~b}$ & $16.8 \mathrm{c}$ & - & $10.5 \mathrm{e}$ & $9.9 \mathrm{f}$ & - \\
NPKS & $13.5 \mathrm{a}$ & $8.7 \mathrm{a}$ & - & $9.3 \mathrm{~cd}$ & $8.4 \mathrm{~d}$ & - \\
\hline
\end{tabular}

Values followed by the same letter in one column indicates that there is no significant difference $(p=0.05)$.

\section{Discussion}

Fertilization has been an essential practice to maintain soil fertility and enhance crop productivity (Edmeades, 2003; Manna et al., 2007). There have been various fertilizer applications, including single or combined mineral fertilizations with/without addition of organic materials. Here, we discuss how different fertilization practices affect SOC dynamics and soil carbon sequestration under various climate and soil conditions.

\subsection{Effect of long-term fertilization on carbon biomass}

Mineral fertilizer applications increase above-ground carbon biomass, while manure in addition shows no significant effect on above-ground carbon biomass at most sites. However, these manure applications sustain the production stability of above-ground biomass, other than the decreasing trend under the control and mineral applications at most studied areas. While the nitrogen application rate is the same for both balanced treatment (i.e., NPK and NPKM), the release of available nitrogen in organic manure is slow, and there is usually competition for available nitrogen between soil microbial and crops under the NPKM application (Zhang et al., 2009). Therefore, mineral and manure combination may not show significant effects on the crop productivity in a relative short-term period (Edmeades, 2003; Zhang et al., 2009). However, there are exceptions. For instance, manure application results in a significant increase of above-ground carbon biomass at the Xuzhou site that has the lowest SOC, soil TN and clay content. There was also evidence from the Rothamsted classical long-term trials due to the long duration (more than $100 \mathrm{yrs}$ ) and larger inputs of manures (Johnston, 1992). These results suggest that perhaps very large differences in soil organic matter are required before the additional benefit of manure, over and over its nutrient content, on crop yield can be observed. On the other hand, the statistical non-difference at the arid and semi-arid areas with monocropping may result from the large inter-annual fluctuations of the above-ground carbon biomass, due to the big differ- ence in biomass productivity between corn and wheat during rotation (Fan et al., 2008). This result would have great effects on the amount and stability of annual carbon input, hence the SOC dynamic, especially for the mineral fertilizer applications.

\subsection{Effect of long-term fertilization on SOC}

Soil carbon sequestration is a homeostasis of SOC decomposition and carbon input. In general, SOC increases when carbon input excess the loss of SOC due to decomposition in agro-ecosystems (Stewart et al., 2007). Soil organic carbon usually decreases when the amount of carbon input into soil from roots and manure is not efficient to maintain SOC level. Mineral applications maintain and/or show a decreasing trend in SOC in the mono-cropping system. Under non-fertilization or unbalanced (i.e., N) fertilization, soil nutrients availability is generally low under continuous cropping, which limits crop growth and leads to low productivity (Singh et al., 2007; Jagadamma et al., 2008). As a result, carbon input from roots is correspondingly low, which affects SOC dynamic and equilibrium. The depletion of SOC and its active fractions decomposed to release nutrients for continuous cropping also partially contribute to the decreasing trend in SOC at most sites under the control and $\mathrm{N}$ application (Manna et al., 2005). Likewisely, balanced mineral fertilization in the mono-cropping system obtain only half the amount of carbon input of that in the double cropping system, hence results in a decreasing trend in SOC in the arid and semi-arid areas. A similar decreasing trend in SOC was also observed in the semi-arid Brazil (Lessa et al., 1996).

Manure applications sustain a significantly increasing trend in SOC, not only in the humid and semi-humid warm temperate areas with the double cropping system, but also in arid and semi-arid areas with the mono-cropping systems, which is widely documented all over the world (Cuvardic et al., 2004; Mando et al., 2005; Galantini and Rosell, 2006; Shen et al., 2007). Apparently, manure application is one way to offset the depletion of SOC due to soil organic material decomposition especially for the dry areas. Crop straw 
(a) GZL

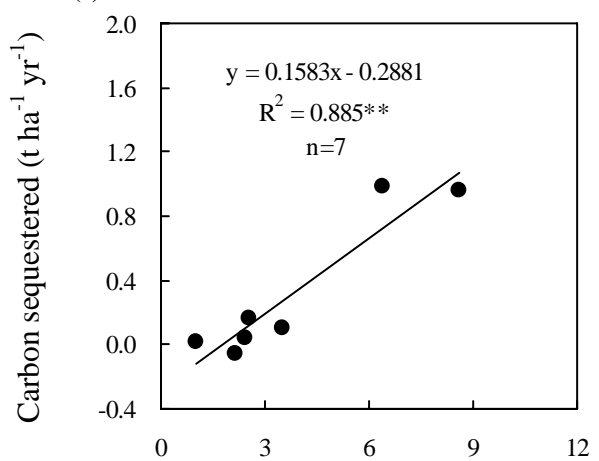

(b) UC

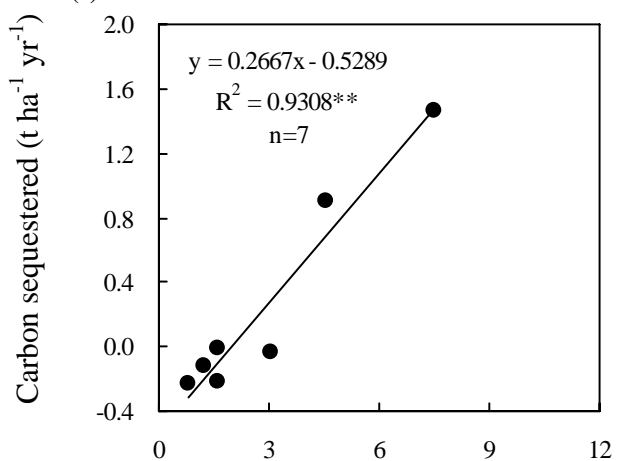

(c) ZY

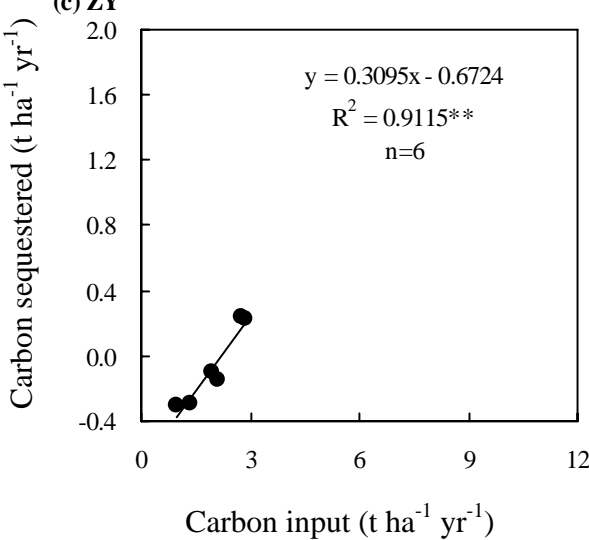

(d) $\mathrm{CP}$

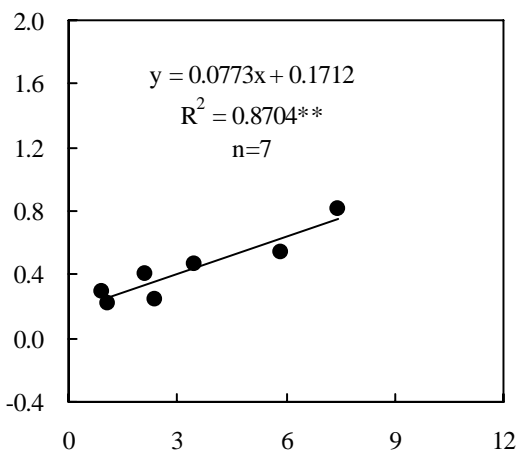

(e) $\mathrm{ZZ}$

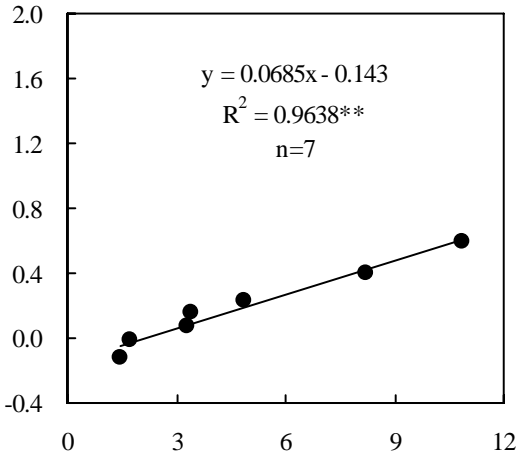

(f) $\mathrm{XZ}$

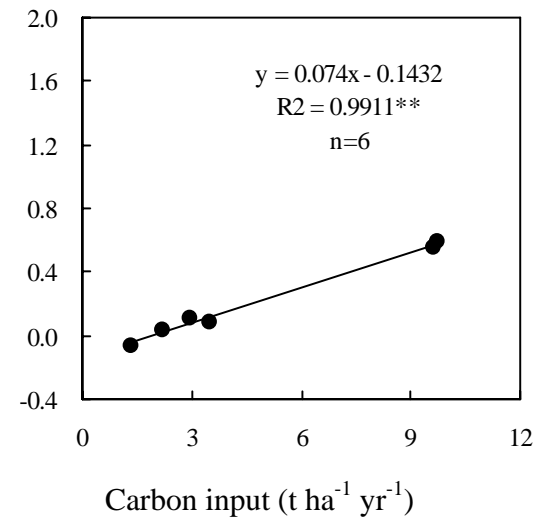

Fig. 6. Correlations between carbon sequestered and carbon input at all sites. Significant correlations are marked with two $(p<0.01)$ asterisks.

incorporated into soil may be difficult to be decomposed in mild-temperate zone because of the relative low temperature (Powlson et al., 2008). Therefore straw incorporation can be commendatory agriculture practices to maintain SOC in the mild-temperate area and sequester carbon soil in warm temperate area.

Soil organic carbon usually changes with carbon input before saturation (Stewart et al., 2007). There is evidence of linear correlation between soil carbon sequestration and carbon input from some long- and/or short-term experiments around the world (Rasmussen and Parton, 1994; Kundu et al., 2001, 2007; Kong et al., 2005; Campbell et al., 2007). This study shows significantly linear correlations between soil carbon sequestration and carbon input. The exception is that at the Xuzhou site, soil organic carbon changed rapidly in the early years and maintained stable in later stage of the study period. Similar results are also found from other longterm experiments (Stewart et al., 2008, 2009). Nevertheless, this study indicates that most upland soils in northern China are not carbon-saturated, having potential to migrating more $\mathrm{CO}_{2}$ from atmosphere. 
(a)

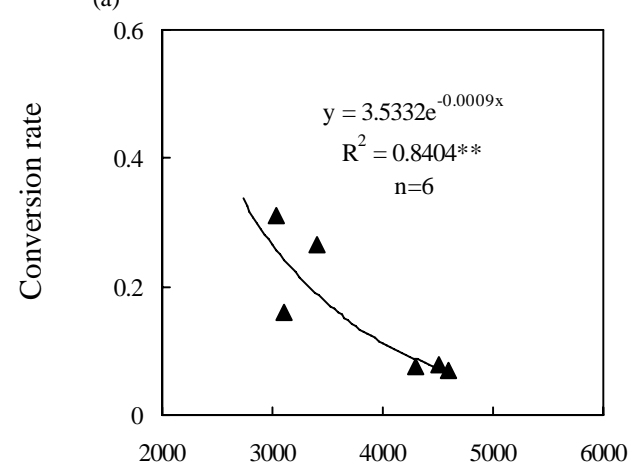

(b)

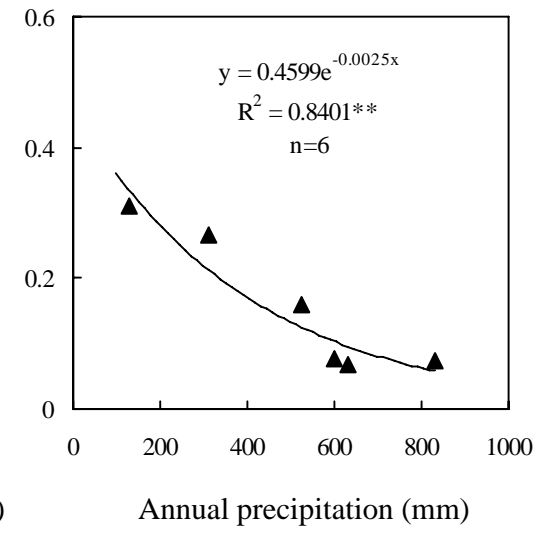

Annual active accumulative temperature $\left({ }^{\circ} \mathrm{C}\right)$

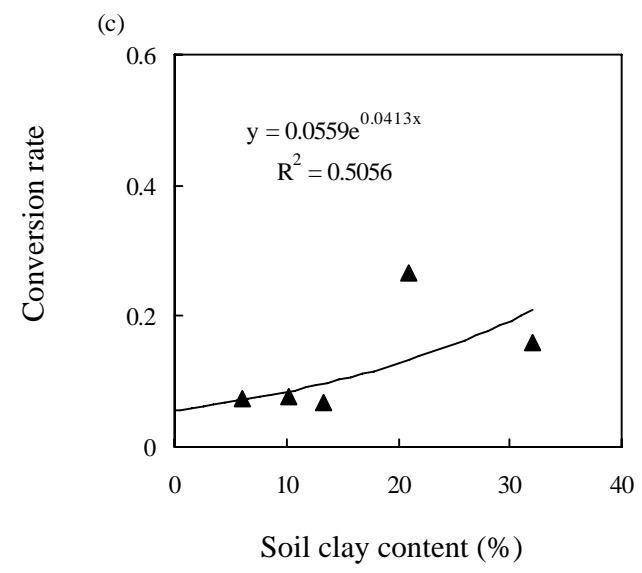

Fig. 7. Relationships between carbon conversion rate and (a) annual active accumulative temperature, (b) annual precipitation, and (c) soil clay content. Significant correlations are marked with two $(p<0.01)$ asterisks.

\subsection{Factors regulating soil carbon sequestration}

Soil carbon sequestration is largely related to environmental conditions such as climate, microbiology, and soil physical and chemical properties (Li et al., 1994; Cihlar, 2007; Gami et al., 2009). The conversion rate at the Urumqi site (26.7\%) is a little higher than those results from semi-arid temperate (14\%-21\%) (Rasmussen and Collins., 1991). The conversion rate in the warm temperate areas $(6.8 \%-7.7 \%)$ is coincident to that of Mediterranean climate (Kong et al., 2005), but much lower than that from the humid subtropical area (19\%) (Kundu et al., 2007).

Our analyses with limited data show significantly relationships between the conversion rates and climate conditions. The conversion rate decreases significantly with the increase in annual active accumulative temperature and precipitation. Under normal conditions, SOC accumulation rate tends to decrease with higher soil temperature and moisture level (Kutsch and Kappen, 1997). It is believed that SOC decomposition responses sensitively to temperature and the decomposition rate usually accelerate with increase in temperature, whether it is more or less than double in every $10^{\circ} \mathrm{C}$ increase in temperature (Davidson and Janssens, 2006). This is to say that low temperature might promote SOC accumulation. The extreme dry climate condition at the Zhangye site (annual precipitation is $127 \mathrm{~mm}$ and evaporation is $2345 \mathrm{~mm}$ ), resulted in the highest conversion rate of all sites. Previous studies also clearly show that carbon sequestration efficiency in the arid and semi-arid regions is much higher than that in humid region (Bolinder et al., 2007; Yan et al., 2007).

Although this study shows no significant relationship between the conversion rate and soil clay content, the conversion rate is much higher in soils rich in clay content than that in soil low in clay content. Other studies have also shown that the potential of soil carbon sequestration in clay soil is much high than soil rich in sandy and silt (Matus et al., 2008; Shi et al., 2009). It is believed that protection of SOC by clay particles has been postulated to occur through at least two separate mechanisms. First, as SOC becomes humified, it is chemically stabilized and adsorbed onto negatively charged clay minerals with high surface area (McLauchlan, 2006). Second, SOC is physically protected from microbial mineralization through the formation of soil aggregates (Franzluebbers et al., 1996). The relationship between clay and 
SOC content is sufficiently strong so that soil carbon models have include such relationship (Muller and Hoper, 2004). For instance, the RothC model (Jenkinson, 1990) and Century model (Parton et al., 1987) assume that SOC decomposition decreases as clay concentration increases.

Soil carbon sequestration seems also related to cropping system. Despite relatively low carbon input in the monocropping systems, the carbon conversion rate is much high. However, such link may actually reflect the close relationships of soil carbon sequestration with soil and/or climate conditions (Al-Kaisi and Grote, 2007; Wang et al., 2009). In addition, the high spatiotemporal heterogeneity of soil conditions such as soil texture is also largely influenced by climate conditions (Huang et al., 2007). Therefore, it is difficult to distinguish the relative roles of cropping system, soil texture, and climate conditions on soil carbon sequestration.

\section{Conclusions}

This study presents SOC dynamics and its response to carbon input under long-term fertilizations in various climate zones in northern China. For the arid and semi-arid areas with mono-cropping system, carbon input under balanced mineral applications (e.g. NP and NPK) is not inadequate to maintain SOC level, leading to a decreasing trend in SOC. Additional application of manure is necessary in these arid and semi-arid areas. For the warm-temperate areas with double cropping system, balanced mineral applications (e.g. NP and NPK), as well as manure and straw incorporation, result in a significant increase and sustain an increasing trend in SOC. Significantly linear relationship between soil carbon sequestration and carbon input suggests these soils have potential to sequester more carbon in northern China. Soil carbon sequestration efficiency has significant correlation with climate conditions. The conversion rate of carbon input in the mild-temperate areas is much higher than that in the warmtemperate areas. In addition, soil texture is also one of the factors that affect the efficiency of soil carbon sequestration. Further studies are needed to better understand the interactive roles of agricultural practice (e.g., cropping system and fertilization) and environmental conditions (e.g., climate and soil conditions) in regulating soil carbon sequestration.

Acknowledgements. We acknowledge all the colleagues for their unremitting efforts on the long-term experiments from these sites. Thanks are given to Ranjan Bhattacharyya and the anonymous reviewer for their constructive comments on this manuscript. We would also like to acknowledge Qiuliang Lei's on his technical work on the map creating. Financial supports are from the National Science Foundation of China (40871148, 40901141) and the 11th Five-Year Key Planning Program of China for Science and Technology (2006BAD05B09, 2006BAD02A14).

Edited by: E. Falge

\section{References}

Al-Kaisi, M. M. and Grote, J. B.: Cropping systems effects on improving soil carbon stocks of exposed subsoil, Soil Sci. Soc. Am. J., 71, 1381-1388, doi:10.2136/sssaj2006.0200, 2007.

Bhattacharyya, R., Chandra, S., Singh, R. D., Kundu, S., Srivastva, A. K., and Gupta, H. S.: Long-term farmyard manure application effects on properties of a silty clay loam soil under irrigated wheat-soybean rotation, Soil Till. Res., 94, 386-396, doi:10.1016/j.still.2006.08.014, 2007.

Black, C. A.: Methods of soil analysis, part 2, Madison, Wisc.: ASA., 1965.

Bolinder, M. A., Andre'n, O., Ka“tterer, T., de Jong, R., VandenBygaart, A. J., Angers, D. A., Parent, L. E., and Gregorich, E. G.: Soil carbon dynamics in Canadian agricultural ecoregions: Quantifying climatic influence on soil biological activity, Agr. Ecosyst. Environ., 122, 461-470, 2007.

Buyanovsky, G. A. and Wagner, G. H.: Carbon cycling in cultivated land and its global significance, Global Change Biol., 4, 131$141,1998$.

Cai, Z. C. and Qin, S. W.: Dynamics of crop yields and soil organic carbon in a long-term fertilization experiment in the Huang-Huai-Hai Plain of China, Geoderma, 136, 708-715, doi:10.1016/j.geoderma.2006.05.008, 2006.

Campbell, C. A., VandenBygaart, A. J., Grant, B., Zentner, R. P., McConkey, B. G., Lemke, R., Gregorichl, E. G., and Fernandez, M. R.: Quantifying carbon sequestration in a conventionally tilled crop rotation study in southwestern Saskatchewan, Can. J. Soil Sci., 87, 23-38, 2007.

Chander, K., Goyal, S., Mundra, M. C., and Kapoor, K. K.: Organic matter, microbial biomass and enzyme activity of soils under different crop rotations in the tropics, Biol. Fert. Soils, 24, 306-310, 1997.

Cihlar, J.: Quantification of the regional carbon cycle of the biosphere: Policy, science and land-use decisions, J. Environ. Manage., 85, 785-790, 2007.

Cuvardic, M., Tveitnes, S., Krogstad, T., and Lombnaes, P.: Longterm effects of crop rotation and different fertilization systems on soil fertility and productivity, Acta Agr. Scand. B-S. P., 54, 193-201, doi:10.1080/09064710410030258, 2004.

Davidson, E. A. and Janssens, I. A.: Temperature sensitivity of soil carbon decomposition and feedbacks to climate change, Nature, 440, 165-173, doi:10.1038/nature04514, 2006.

Dominy, C. S., Haynes, R. J., and van Antwerpen, R.: Loss of soil organic matter and related soil properties under long-term sugarcane production on two contrasting soils, Biol. Fert. Soils, 36, 350-356, doi:10.1007/s00374-002-0538-5, 2002.

Edmeades, D. C.: The long-term effects of manures and fertilisers on soil productivity and quality: A review, Nutr. Cycl. Agroecosys., 66, 165-180., 2003.

Fan, T. L., Stewart, B. A., Payne, W. A., Yong, W., Luo, J. J., and Gao, Y. F.: Long-term fertilizer and water availability effects on cereal yield and soil chemical properties in Northwest China, Soil Sci. Soc. Am. J., 69, 842-855, doi:10.2136/sssaj2004.0150, 2005.

Fan, T. L., Xu, M. G., Song, S. Y., Zhou, G. Y., and Ding, L. P.: Trends in grain yields and soil organic $\mathrm{C}$ in a long-term fertilization experiment in the China Loess Plateau, J. Plant Nutr. Soil Sc., 171, 448-457, 2008.

FAO-UNESCO: Soil map of the world: Revised legend, World Soil 
Resources Report No. 60, FAO, Rome, 1988.

Franzluebbers, A. J., Haney, R. L., Hons, F. M., and Zuberer, D. A.: Active fractions of organic matter in soils with different texture, Soil Biol. Biochem., 28, 1367-1372, 1996.

Freibauer, A., Rounsevell, M. D. A., Smith, P., and Verhagen, J.: Carbon sequestration in the agricultural soils of Europe, Geoderma, 122, 1-23, 2004.

Galantini, J., and Rosell, R.: Long-term fertilization effects on soil organic matter quality and dynamics under different production systems in semiarid pampean soils, Soil Till. Res., 87, 72-79, doi:10.1016/j.still.2005.02.032, 2006.

Gami, S. K., Lauren, J. G., and Duxbury, J. M.: Influence of soil texture and cultivation on carbon and nitrogen levels in soils of the eastern Indo-Gangetic Plains, Geoderma, 153, 304-311, 2009.

Gong, W., Yan, X., Wang, J., Hu, T., and Gong, Y.: Long-term manure and fertilizer effects on soil organic matter fractions and microbes under a wheat-maize cropping system in northern China, Geoderma, 149, 318-324, 2009.

Gulde, S., Chung, H., Amelung, W., Chang, C., and Six, J.: Soil carbon saturation controls labile and stable carbon pool dynamics, Soil Sci. Soc. Am. J., 72, 605-612, doi:10.2136/sssaj2007.0251, 2008.

Hassink, J.: The capacity of soils to preserve organic $\mathrm{C}$ and $\mathrm{N}$ by their association with clay and silt particles, Plant Soil, 191, 7787, 1997.

He, X., Izaurralde, R. C., Vanotti, M. B., Williams, J. R., and Thomson, A. M.: Simulating long-term and residual effects of nitrogen fertilization on corn yields, soil carbon sequestration, and soil nitrogen dynamics, J. Environ. Qual., 35, 1608-1619, doi:10.2134/jeq2005.0259, 2006.

Huang, B., Sun, W. X., Zhao, Y. C., Zhu, J., Yang, R. Q., Zou, Z., Ding, F., and Su, J. P.: Temporal and spatial variability of soil organic matter and total nitrogen in an agricultural ecosystem as affected by farming practices, Geoderma, 139, 336-345, 10.1016/j.geoderma.2007.02.012, 2007.

Huang, Y., and Sun, W. J.: Changes in topsoil organic carbon of croplands in mainland china over the last two decades, Chinese Sci. Bull., 51, 1785-1803, doi:10.1007/s11434-006-2056-6, 2006.

Jagadamma, S., Lal, R., Hoeft, R. G., Naffiger, E. D., and Adee, E. A.: Nitrogen fertilization and cropping system impacts on soil properties and their relationship to crop yield in the central corn belt, USA, Soil Till. Res., 98, 120-129, 10.1016/j.still.2007.10.008, 2008.

Jenkinson, D. S.: The turnover of organic carbon and nitrogen in soil, Philos. T. Roy. Soc. B, 329, 361-367, 1990.

Johnston, A. E.: The rothamsted classical experiments, in: Longterm Experiments in Agricultural and Ecological Sciences, edited by: Leigh, R. A. and Johnston, A. E., CAB International, Walling-ford, UK, 1992.

Kätterer, T., Reichstein, M., Andren, O., and Lomander, A.: Temperature dependence of organic matter decomposition: A critical review using literature data analyzed with different models, Biol. Fert. Soils, 27, 258-262., 1998.

Kong, A. Y. Y., Six, J., Bryant, D. C., Denison, R. F., and van Kessel, C.: The relationship between carbon input, aggregation, and soil organic carbon stabilization in sustainable cropping systems, Soil Sci. Soc. Am. J., 69, 1078-1085, doi:10.2136/sssaj2004.0215, 2005.
Kong, X., Dao, T. H., Qin, J., Qin, H., Li, C., and Zhang, F.: Effects of soil texture and land use interactions on organic carbon in soils in north China cities' urban fringe, Geoderma, 154, 86-92, 2009.

Kundsen, D., Peterson, G. A., Pratt, P. F., and Page, A. L.: Lithium, sodium, and potassium, in: Methods of Soil Analysis, part 2, 2nd Ed., Madison, Wisc: ASA and SSSA, 225-246, 1982.

Kundu, S., Singh, M., Saha, J. K., Biswas, A., Tripathi, A. K., and Acharya, C. L.: Relationship between c addition and storage in a vertisol under soybean-wheat cropping system in sub-tropical central india, J. Plant Nutr. Soil Sc., 164, 483-486, 2001.

Kundu, S., Bhattacharyya, R., Prakash, V., Ghosh, B. N., and Gupta, H. S.: Carbon sequestration and relationship between carbon addition and storage under rainfed soybean-wheat rotation in a sandy loam soil of the Indian Himalayas, Soil Till. Res., 92, 8795, doi:10.1016/j.still.2006.01.009, 2007.

Kutsch, W. L. and Kappen, L.: Aspects of carbon and nitrogen cycling in soils of the bornhoved lake district .2. Modelling the influence of temperature increase on soil respiration and organic carbon content in arable soils under different managements, Biogeochemistry, 39, 207-224, 1997.

Kuzyahov, Y. and Domenski, G.: Carbon input by plants into the soil, J. Plant Nutr. Soil Sc., 163, 421-431, 2000.

Lal, R.: Soil carbon dynamics in cropland and rangeland, Environ. Pollut., 116, 353-362, 2002.

Lal, R.: Offsetting China 's $\mathrm{CO}_{2}$ emissions by soil carbon sequestration, Climatic Change, 65, 263-275, 2004.

Lal, R.: Enhancing crop yields in the developing countries through restoration of the soil organic carbon pool in agricultural lands, Land Degrad. Dev., 17, 197-209, 2006.

Lessa, A. S. N., Anderson, D. W., and Moir, J. O.: Fine root mineralization, soil organic matter and exchangeable cation dynamics in slash and burn agriculture in the semi-arid northeast of Brazil, Agr. Ecosyst. Environ., 59, 191-202, 1996.

Li, C. S., Frolking, S., and Harriss, R.: Modeling carbon biogeochemistry in agricultural soils, Global Biogeochem. Cy., 8, 237 254, 1994.

Lu, R. K.: Analytical methods of soil agricultural chemistry, Beijing: China Agricultural Science and Technology Press, 2000 (in Chinese).

Mando, A., Bonzi, M., Wopereis, M. C. S., Lompo, F., and Stroosnijder, L.: Long-term effects of mineral and organic fertilization on soil organic matter fractions and sorghum yield under sudano-sahelian conditions, Soil Use Manage., 21, 396-401, doi:10.1079/sum2005339, 2005.

Manna, M. C., Swarup, A., Wanjari, R. H., Ravankar, H. N., Mishra, B., Saha, M. N., Singh, Y. V., Sahi, D. K., and Sarap, P. A.: Longterm effect of fertilizer and manure application on soil organic carbon storage, soil quality and yield sustainability under subhumid and semi-arid tropical India, Field Crop. Res., 93, 264280, doi:10.1016/j.fcr.2004.10.006, 2005.

Manna, M. C., Swarup, A., Wanjari, R. H., Mishra, B., and Shahi, D. K.: Long-term fertilization, manure and liming effects on soil organic matter and crop yields, Soil Till. Res., 94, 397-409, 2007.

Matus, F. J., Lusk, C. H., and Maire, C. R.: Effects of soil texture, carbon input rates, and litter quality on free organic matter and nitrogen mineralization in Chilean rain forest and agricultural soils, Commun. Soil Sci. Plan., 39, 187-201, doi:10.1080/00103620701759137, 2008. 
McLauchlan, K. K.: Effects of soil texture on soil carbon and nitrogen dynamics after cessation of agriculture, Geoderma, 136, 289-299, 2006.

Muller, T. and Hoper, H.: Soil organic matter turnover as a function of the soil clay content: Consequences for model applications, Soil Biol. Biochem., 36, 877-888, 2004.

Murphy, J. and Riley, J. P.: A modified of single solution method for the determination of phosphate in nature water, Anal. Chim. Acta, 27, 31-36, 1962.

NCATS: Chinese organic fertilizer handbook, National Center for Agricultural Technology Service, Chinese Agricultural Publisher, 200, 1994.

NSSO: National soil survey office, soils of China, China Agrucultural Press, Beijing, 1998 (in Chinese).

Olsen, S. R., Cole, C. V., Watanabe, F. S., and Dean, A.: Estimation of available phosphorus in soils by extraction with sodium bicarbonate, (USDA Circ. 939). Washington, D.C.: U.S. Government Printing Office, 1954.

Pan, G., Smith, P., and Pan, W.: The role of soil organic matter in maintaining the productivity and yield stability of cereals in China, Agr. Ecosyst. Environ., 129, 344-348, 2009.

Parton, W. J., Schimel, D. S., Cole, C. V., and Ojima, D. S.: Analysis of factors controlling soil organic matter levels on great plains grasslands, Soil Sci. Soc. Am. J., 51, 1173-1179, 1987.

Paustian, K., Cole, C. V., Sauerbeck, D., and Sampson, N.: CO2 mitigation by agriculture: An overview, Climatic Change, 40, 135-162., 1998.

Post, W. M., Izaurralde, R. C., Jastrow, J. D., McCarl, B. A., Amonette, J. E., Bailey, V. L., Jardine, P. M., West, T. O., and Zhou, J. Z.: Enhancement of carbon sequestration in us soils, Bioscience, 54, 895-908, 2004.

Powlson, D. S., Riche, A. B., Coleman, K., Glendining, N., and Whitmore, A. P.: Carbon sequestration in European soils through straw incorporation: Limitations and alternatives, Waste Manage., 28, 741-746, doi:10.1016/j.wasman.2007.09.024, 2008.

Purakayastha, T. J., Rudrappa, L., Singh, D., Swarup, A., and Bhadraray, S.: Long-term impact of fertilizers on soil organic carbon pools and sequestration rates in maizewheat.-cowpea cropping system, Geoderma, 144, 370-378, doi:10.1016/j.geoderma.2007.12.006, 2008.

Rasmussen, P. E. and Parton, W. J.: Long-term effects of residue management in wheat-fallow .1. Inputs, yield, and soil organicmatter, Soil Sci. Soc. Am. J., 58, 523-530, 1994.

Rasmussen, P. E., and Collins., H. P.: Long-term impacts of tillage, fertilizer, and crop residue on soil organic matter in temperate semiarid regions, Adv. Agron., 45, 93-134, 1991.

Reichstein, M., Tenhunen, J. D., Roupsard, O., Ourcival, J. M., Rambal, S., Miglietta, F., Peressotti, A., Pecchiari, M., Tirone, G., and Valentini, R.: Severe drought effects on ecosystem $\mathrm{CO}_{2}$ and $\mathrm{H}_{2} \mathrm{O}$ fluxes at three mediterranean evergreen sites: Revision of current hypotheses?, Global Change Biol., 8, 999-1017, 2002.

Schlesinger, W. H.: Carbon and agriculture - carbon sequestration in soils, Science, 284, 2095-2095, 1999.

Shen, M. X., Yang, L. Z., Yao, Y. M., Wu, D. D., Wang, J. G., Guo, R. L., and Yin, S. X.: Long-term effects of fertilizer managements on crop yields and organic carbon storage of a typical rice-wheat agroecosystem of China, Biol. Fert. Soils, 44, 187200, doi:10.1007/s00374-007-0194-x, 2007.
Shi, X. Z., Wang, H. J., Yu, D. S., Weindorf, D. C., Cheng, X. F., Pan, X. Z., Sun, W. X., and Chen, J. M.: Potential for soil carbon sequestration of eroded areas in subtropical China, Soil Till. Res., 105, 322-327, 2009.

Singh, K. P., Suman, A., Singh, P. N., and Lal, M.: Yield and soil nutrient balance of a sugarcane plant-ratoon system with conventional and organic nutrient management in sub-tropical India, Nutr. Cycl. Agroecosys., 79, 209-219, doi:10.1007/s10705-0079108-4, 2007.

Six, J., Conant, R. T., Paul, E. A., and Paustian, K.: Stabilization mechanisms of soil organic matter: Implications for C-saturation of soils, Plant Soil, 241, 155-176, 2002.

Smith, O. H., Petersen, G. W., and Needelman, B. A.: Environmental indicators of agroecosystems, Adv. Agron., 69, 75-97, 1999.

Soil Science Society of China: Methods of soil agrochemistry analysis, Chinese Agriculture Science and Technology Press, Beijing, China, 2000 (in Chinese).

Stewart, C. E., Paustian, K., Conant, R. T., Plante, A. F., and Six, J.: Soil carbon saturation: Concept, evidence and evaluation, Biogeochemistry, 86, 19-31, doi:10.1007/s10533-007-9140-0, 2007.

Stewart, C. E., Plante, A. F., Paustian, K., Conant, R. T., and Six, J.: Soil carbon saturation: Linking concept and measurable carbon pools, Soil Sci. Soc. Am. J., 72, 379-392, doi:10.2136/sssaj2007.0104, 2008.

Stewart, C. E., Paustian, K., Conant, R. T., Plante, A. F., and Six, J.: Soil carbon saturation: Implications for measurable carbon pool dynamics in long-term incubations, Soil Biol. Biochem., 41, 357-366, 2009.

Su, Y. Z., Wang, F., Suo, D. R., Zhang, Z. H., and Du, M. W.: Longterm effect of fertilizer and manure application on soil-carbon sequestration and soil fertility under the wheat-wheat-maize cropping system in northwest China, Nutr. Cycl. Agroecosys., 75, 285-295, doi:10.1007/s10705-006-9034-x, 2006.

Tong, C., Xiao, H., Tang, G., Wang, H., Huang, T., Xia, H., Keith, S. J., Li, Y., Liu, S., and Wu, J.: Long-term fertilizer effects on organic carbon and total nitrogen and coupling relationships of $\mathrm{C}$ and $\mathrm{N}$ in paddy soils in subtropical China, Soil Till. Res., 106, 8-14, 2009.

Vinther, F. P., Hansen, E. M., and Olesen, J. E.: Effects of plant residues on crop performance, $\mathrm{N}$ mineralisation and microbial activity including field $\mathrm{CO}_{2}$ and $\mathrm{N}_{2} \mathrm{O}$ fluxes in unfertilised crop rotations, Nutr. Cycl. Agroecosys., 70, 189-199, 2004.

Walkley, A. and Black, I. A.: An examination of the degtjareff method for determining soil organic matter and a proposed modification of the chromic acid titration method, Soil Sci., 37, 29-38, 1934.

Wang, Q., Wang, S., and Zhang, J.: Assessing the effects of vegetation types on carbon storage fifteen years after reforestation on a Chinese fir site, Forest Ecol. Manag., 258, 1437-1441, 2009.

Xie, Z. B., Zhu, J. G., Liu, G., Cadisch, G., Hasegawa, T., Chen, C. M., Sun, H. F., Tang, H. Y., and Zeng, Q.: Soil organic carbon stocks in China and changes from 1980s to 2000s, Global Change Biol., 13, 1989-2007, doi:10.1111/j.13652486.2007.01409.x, 2007.

Yan, H., Cao, M., Liu, J., and Tao, B.: Potential and sustainability for carbon sequestration with improved soil management in agricultural soils of China, Agr. Ecosyst. Environ., 121, 325-335, 2007. 
Yang, X. M., Zhang, X. P., Fang, H. J., Zhu, P., Ren, J., and Wang, L. C.: Long-term effects of fertilization on soil organic carbon changes in continuous corn of Northeast China: Rothc model simulations, Environ. Manage., 32, 459-465, doi:10.1007/s00267-003-0082-6, 2003.
Zhang, H., Xu, M., and Zhang, F.: Long-term effects of manure application on grain yield under different cropping systems and ecological conditions in China, J. Agr. Sci., 147, 31-42, doi:10.1017/S0021859608008265, 2009. 